\title{
CHINESE ZADELTAPIJTEN: DE BETEKENIS VAN HISTORISCH BEELDMATERIAAL
}

Als kunsthistoricus en privéverzamelaar van vroege Chinese kunst raakte ik gedurende het afgelopen decennium steeds meer geïnteresseerd in Chinese tapijten. De reden is, dat daarover tot voor kort maar weinig bekend was. Algemeen werd aangenomen dat het knopen van tapijten van wol of zijde een kunst was die de Chinezen betrekkelijk laat, dat wil zeggen tegen het eind van de $17^{\mathrm{e}}$ eeuw ten tijde van de Manchu keizer Kangxi (1661-1722), van Centraal Aziatische volkeren hebben overgenomen. Ronduit fascinerend vind ik nog steeds het gegeven dat als je een Chinees vertelt over de belangrijke rol die de tapijtkunst van oudsher in China heeft gespeeld, hij je steevast ongelovig aankijkt. Immers, hij associeert China met zijde en in mindere mate met katoen, maar zeker niet met wol. Dat zegt veel over de Chinese identiteit. Het Chinese cultuurbesef en het daarop gebaseerde onderwijs vereenzelvigt Chinees tot op de dag van vandaag met Han-Chinees en gaat daarmee voorbij aan het feit dat een groot deel van China wordt bewoond door volkeren die geen Han-Chinezen en dus eigenlijk 'barbaren' zijn. Maar, trek een denkbeeldige diagonale lijn van noordoost naar zuidwest China en realiseer je dan dat het in de linkerhelft in de winter bar koud is. De daar levende bevolking, of dat nu veehoudende nomaden, gevestigde boeren of burgers waren, had behoefte aan goed isolerend materiaal zoals vilt en geweven of geknoopte wol voor de tentwoning (yurt), huisraad en kleding om zich tegen de kou te beschermen.

Paarden en andere rij-, trek- en lastdieren hebben in de geschiedenis van China een onmisbare rol in de verdediging van de landsgrenzen gehad. Hierdoor wordt direct duidelijk dat het bestuderen van deze dieren veel kennis oplevert. Dat blijft niet beperkt tot hun bewaard gebleven tuigage, maar - juist - ook van de afbeeldingen ervan.

Heersers hebben nu eenmaal de gewoonte om vooral hun heroïsche daden te vereeuwigen in woord en beeld. Dat heeft geleid tot een onafzienbare reeks afbeeldingen van ruiters tijdens veldtochten, staatsbezoeken, jachtpartijen, processies et cetera en daardoor in een dienovereenkomstig aantal afbeeldingen van zadeltapijten.

In de laatste decennia is een flink deel van de kennisachterstand op het gebied van Chinese tapijten ingelopen en dan vooral door de publicaties van Michael Franses en Hans König. ${ }^{1}$ De resten van geknoopte wollen tapijten die opgegraven zijn in de kurkdroge Taklamakan woestijn worden op basis van $\mathrm{C}-14$ onderzoek gedateerd in de eerste eeuwen van onze jaartelling. $\mathrm{Zij}$ hebben ons geleerd dat China, vermoedelijk via de toen al intensief benutte zijderoutes, kennis had gemaakt met deze kunstvorm. De vraag blijft intussen of het daarbij om import of door Chinezen zelf geproduceerde tapijten gaat. Uit literaire bronnen is bekend dat al tijdens de Yuan-dynastie (1279-1368) een atelier in Dadu, de Mongoolse hoofdstad die iets ten noorden van het 
Afb. 1

\section{Grafbeeld van een} gezadeld paard, koud beschilderd aardewerk, h. 24 cm., China, eerste helft $6^{e}$ eeuw (Noordelijke Wei-dynastie), Rijksmuseum Amsterdam, inv.nr. Ak-Mak533. Legaat Westendorp 1968 , in permanent bruikleen van de VVAK.

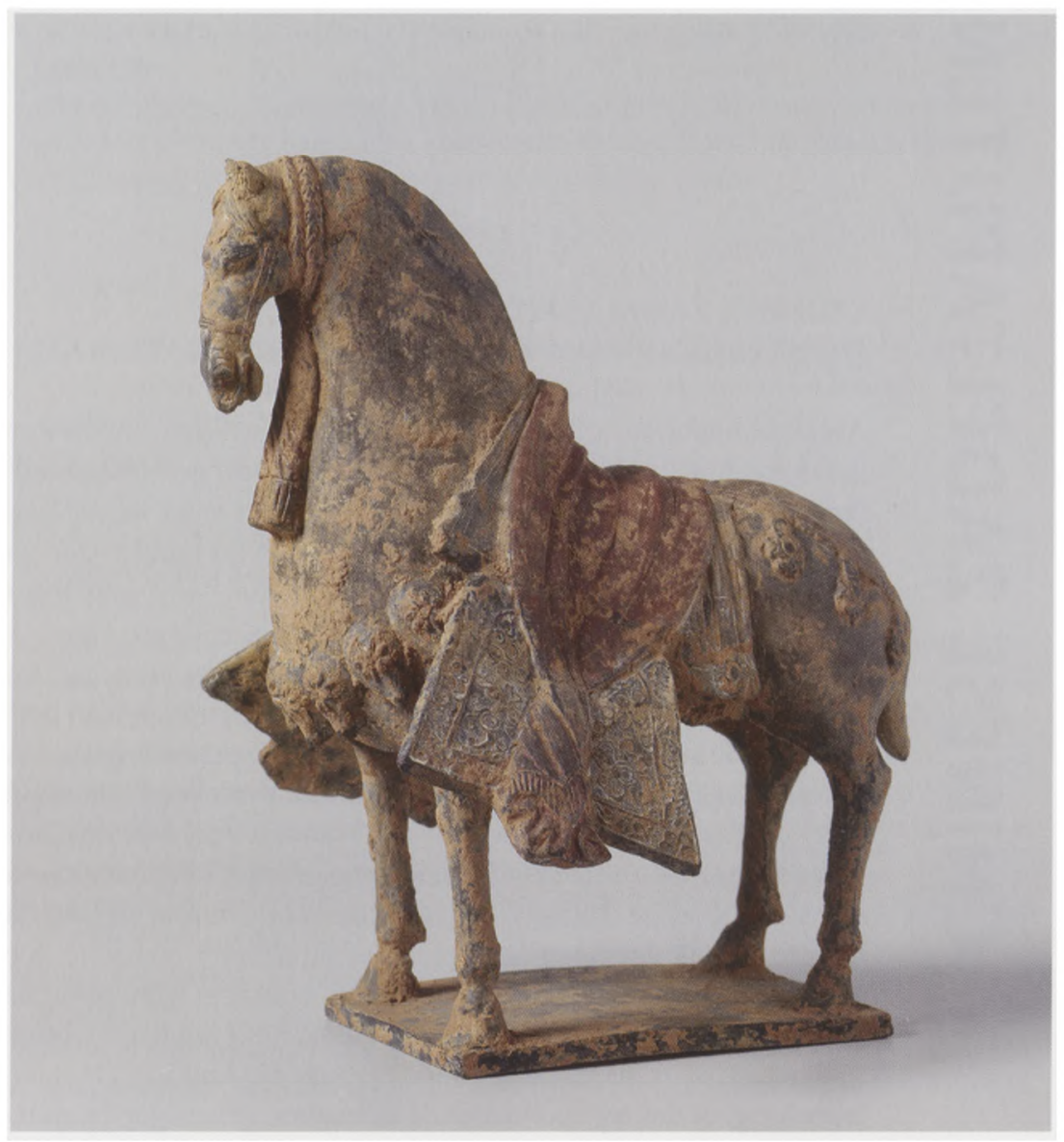

huidige Beijing lag, tapijten produceerde. We weten zeker dat in opdracht van de Ming-keizer Yongle (1403-24) grote tapijten werden geknoopt voor zijn paleis, de huidige Verboden Stad, dat hij liet bouwen in de nieuwe hoofdstad Beijing. Van deze vroege Ming-tapijten zijn slechts enkele fragmenten bewaard gebleven. Een aanzienlijk deel van de immens grote paleistapijten die in opdracht van keizer Wanli (1573-1620) werden vervaardigd, als ook van die uit de tijd van de Qing-keizers Kangxi (16541722), Yongzheng (1723-35) en Qianlong (1736-95), hebben daarentegen de tijd relatief goed doorstaan. Opgeborgen in een verzegeld depot in de Verboden Stad en totaal vergeten werden ruim 300 tapijten tien jaar geleden door Michael Franses ontdekt. ${ }^{2}$ Daarmee kon definitief worden afgerekend met de heersende opvatting dat alle tapijten relatief laat en niet echt 'Chinees' zijn.

Desalniettemin was er tot nu toe weinig of niets bekend over zadeltapijten. Vandaar dat ze gemakshalve bijna allemaal worden omschreven als Chinees en gedateerd in de $19^{\mathrm{e}}$ eeuw.

Dat vormde voor mij de aanleiding om mij verder in het onderwerp te verdiepen. Hoewel het aanvankelijk mijn bedoeling was om een artikel te schrijven, leverde het onderzoek zo veel interessant materiaal op, dat het uiteindelijk uitmondde in een boek. ${ }^{3}$ Voordat ik verder in ga op wat mijn onderzoek heeft opgeleverd, wil ik hier eerst even kort stilstaan bij de

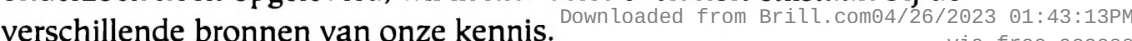


Deze kennis was en is voor een deel nog steeds gebaseerd op het bestuderen van de tapijten zelf. Behoudens enkele vooral Duitstalige kunsthistorici waren het voornamelijk tapijthandelaren die zich daarmee bezighielden. Hun kennis stoelde in hoofdzaak op wat we tegenwoordig 'hands on' ervaring noemen en was dus van praktische aard. Deze situatie veranderde echter toen sommige gespecialiseerde handelaren, verzamelaars en museumconservatoren gingen samenwerken, de resultaten van hun onderzoek uitwisselden en in 1978 het aanvankelijk Engels/Duitstalige, later Engelstalige tijdschrift Hali uitgaven, door middel waarvan zij zich een internationaal forum verschaften. Een tweede factor van belang was de groeiende betekenis van het structureel analyseren van tapijten, een ontwikkeling die alles te maken had met de professionalisering van de opleiding tot textielrestaurator, evenals de standaardisatie van de terminologie voor het beschrijven van tapijten en ander textiel. ${ }^{4}$

Gedurende de laatste decennia is ook de datering door middel van C-14 onderzoek steeds belangrijker geworden. Meer van de laatste tijd is het dateren van tapijten door het analyseren van de gebruikte kleurstoffen en de verwachtingen zijn hoog gespannen ten aanzien van het doen van genetisch onderzoek naar de herkomst van de gebruikte natuurlijke materialen. Andere bronnen zijn de Chinese literatuur en vanzelfsprekend ook de bewaard gebleven archieven. De waarde van deze bronnen is vooralsnog beperkt, omdat de gebruikte terminologie onduidelijk en soms ronduit verwarrend is. Van een wetenschappelijke bestudering van artefacten, literaire en archivalische bronnen naar onze Westerse maatstaven ${ }^{5}$ is eigenlijk pas sprake sinds het einde van de Culturele Revolutie (1976). Sindsdien volgen de spectaculaire vondsten elkaar in hoog tempo op en het einde daarvan is nog lang niet in zicht.

Afb. 2 Muurschildering Optocht van ambassadeurs (detail), Aphrasiab Paleis, Oezbekistan, $6^{\circ}$ eeuw.
De bron die tot nog toe het meest heeft opgeleverd wordt gevormd door het grote aantal schilderijen waarop tapijten zijn afgebeeld. Die 'klassieke' weg ben ik dus ook ingeslagen, net zoals 100 jaar voor mij onderzoekers als Julius Lessing en Wilhelm von Bode en in de jaren 80 en 90 van de vorige eeuw de Engelsman John Mills en onze landgenoot Onno Ydema. ${ }^{6} \mathrm{Zij}$ hielden zich in

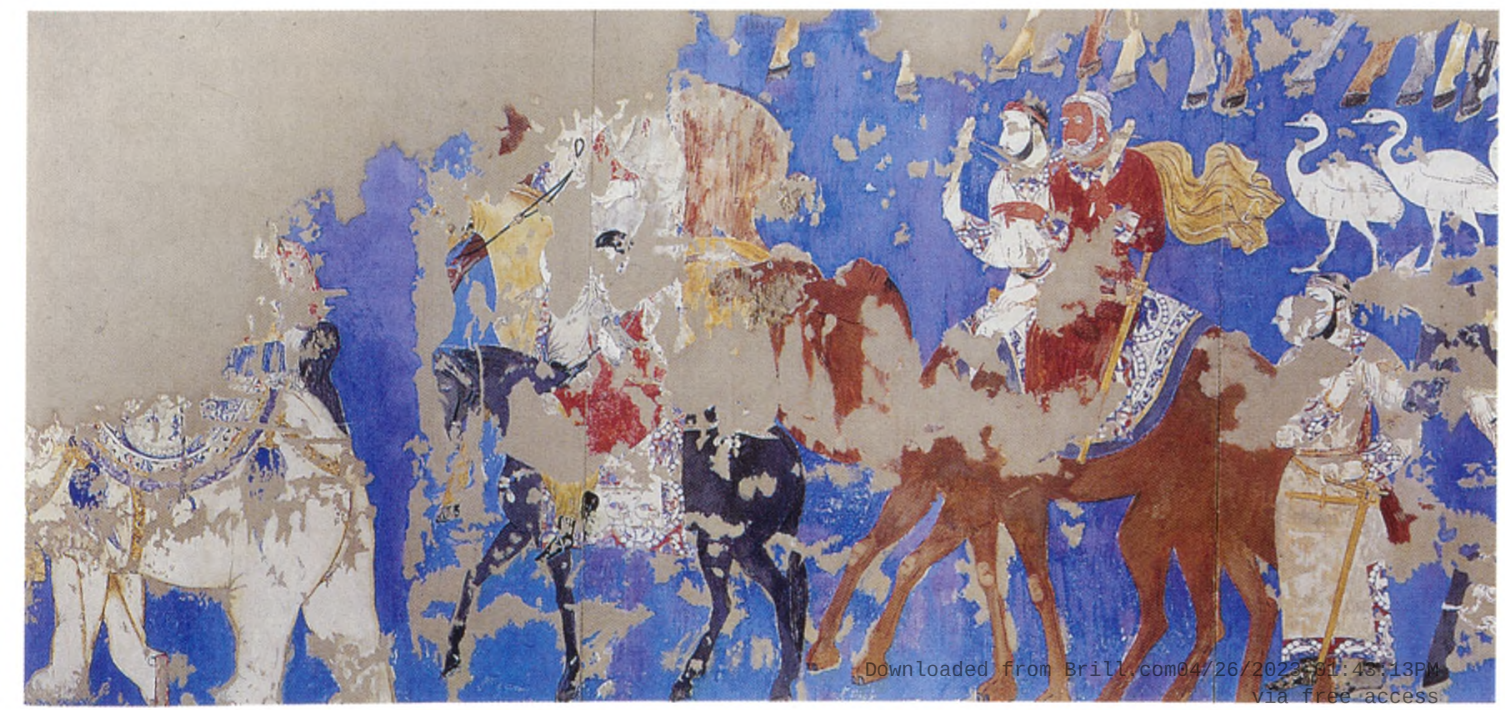



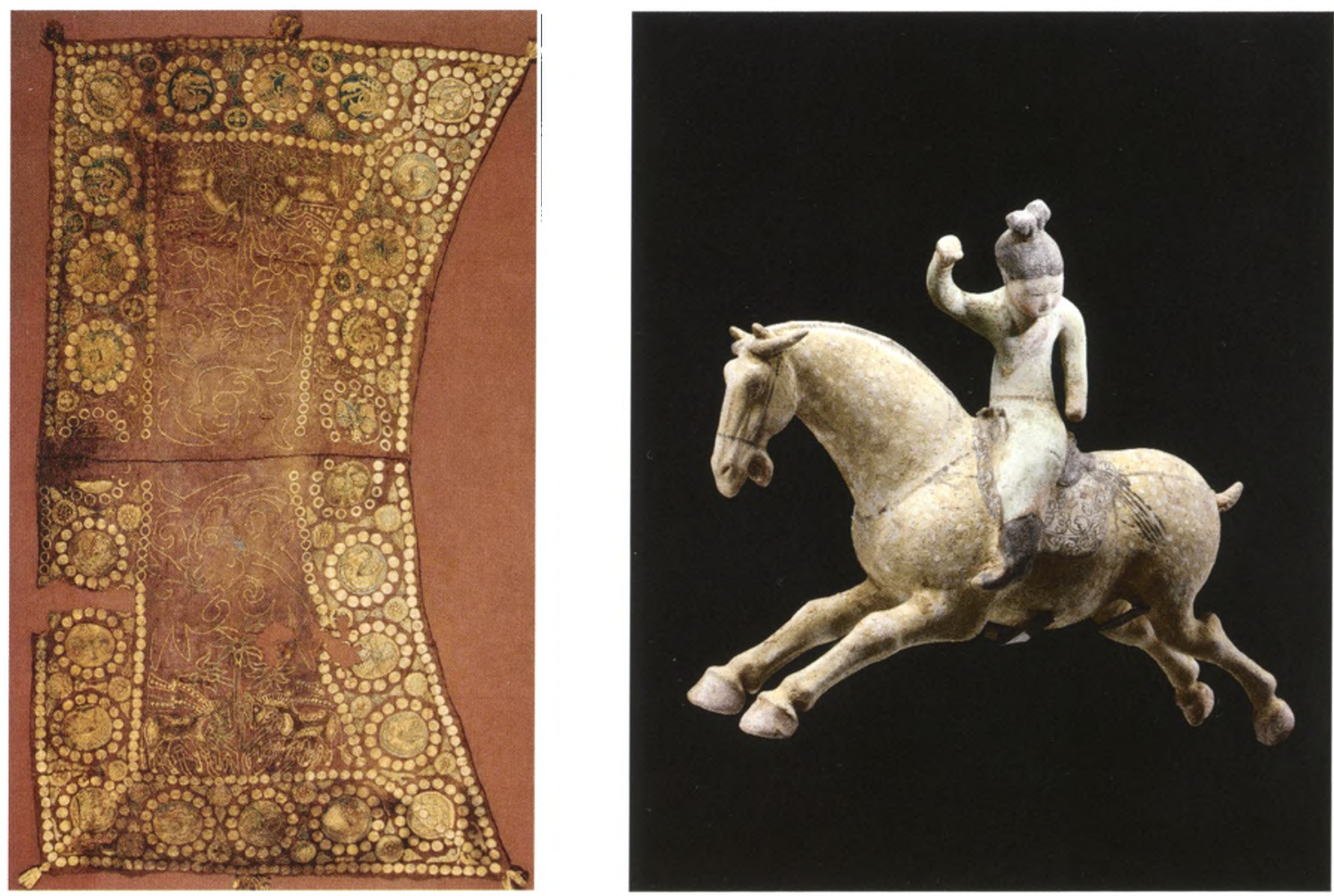

Afb. 3 (links)

Zadelkleed, geborduurde zijde met dessin, 63,5 x 117,7 cm., Centraal-Azië (Sogdië), C-14 gedateerd 450-650, Judy Brick Freedman Collectie.

Afb. 4

Grafbeeld van een polospeelster, koud beschilderd aardewerk, h. $35 \mathrm{~cm}$., China, eerste kwart $7^{e}$ eeuw (Tangdynastie), Musée Guimet, Parijs. hoofdzaak bezig met schilderijen waarop tapijten uit Turkije, Perzië en India te zien zijn, met de bedoeling voor verschillende typen tapijten een zogenaamde datum ante quem vast te stellen. Mijn onderzoek ging nog een stap verder. Behalve de schilderkunst heb ik ook gekeken naar de beeldhouwkunst en toegepaste kunsten. Al spoedig bleek dat juist ook deze andere kunstvormen soms heel gedetailleerde afbeeldingen opleveren. Kennelijk waren de desbetreffende kunstenaars er op uit om de werkelijkheid zo getrouw mogelijk weer te geven. Wellicht heeft dat te maken met het feit dat in de Aziatische cultuur minder waarde wordt gehecht aan de innovatieve rol van de kunstenaar. Integendeel: het navolgen van de conventies en van de grote meesters is hier het uitgangspunt. Dit in tegenstelling tot het Westen waar sinds de Renaissance de inventio juist hoog wordt aangeslagen.

In het kader van mijn onderzoek bestudeerde ik afbeeldingen in handboeken, gespecialiseerde monografieën, museum-, tentoonstellings- en veilingcatalogi, tijdschriften en - hoe kan het tegenwoordig ook anders - het internet.

Een dergelijk, in essentie, stilistisch onderzoek kent zeker ook zijn beperkingen. Toch stelde het uiteindelijke resultaat mij in staat om een redelijk betrouwbare typologie te ontwikkelen aan de hand waarvan in veel gevallen de herkomst en datering van de bewaard gebleven zadeltapijten kan worden bepaald. Hoewel niet het doel van mijn onderzoek, heb ik uiteraard niet nagelaten om de resultaten van een structurele analyse van de zadeltapijten in mijn eigen collectie, evenals de sporadisch door anderen gepubliceerde relevante technische gegevens, te gebruiken om deze typologie verder te onderbouwen. 


\section{Afb. 5}

Rolschildering Paard en valkenier, toegeschreven aan Chen Juzhong, $24,8 \times 26,3 \mathrm{~cm}$., China, eerste helft $13^{\mathrm{e}}$ eeuw (Zuidelijke Songdynastie), Brits Museum, Londen.

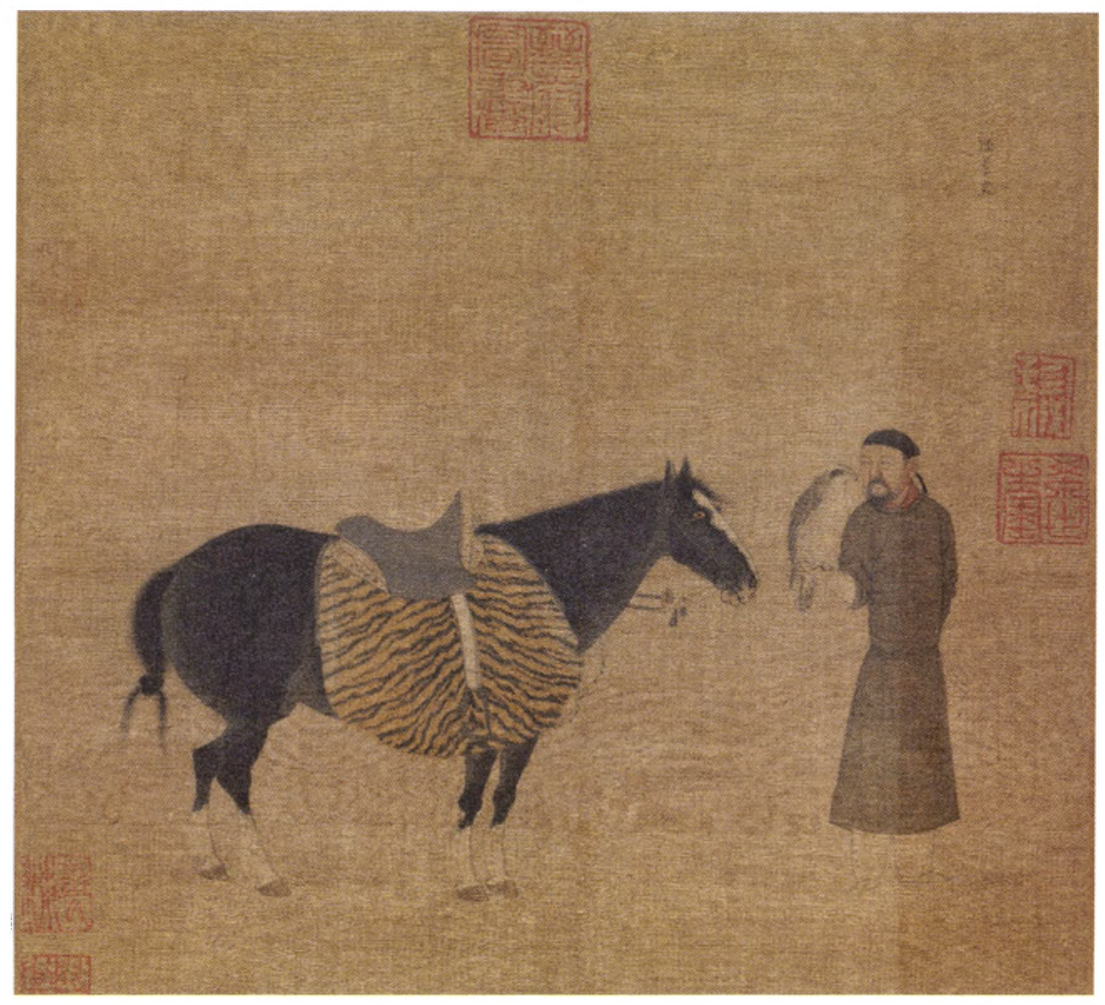

Het is natuurlijk niet de bedoeling en ook niet goed mogelijk om hier mijn boek nog eens dunnetjes over te doen. Vandaar dat ik mij beperk tot afbeeldingen uit opeenvolgende periodes, die in het kader van mijn onderzoek essentieel zijn geweest voor een goed begrip van de tuigage van paarden in het algemeen of van bijzondere onderdelen daarvan.

En wat is er nu leuker dan om mijn reeks te beginnen met nota bene een keramische sculptuur (afb. 1) uit de collectie van de VVAK? Het stuk werd in 1968 door mevrouw J.E. Westendorp-Osieck ter nagedachtenis aan haar overleden echtgenoot Mr. H.K. Westendorp, stichter en eerste voorzitter van de VVAK, aan onze vereniging geschonken en wordt sindsdien door het Rijksmuseum gekoesterd als een van de topstukken. Dit soort sculpturen werd in China als mingqi (grafgift) meegegeven aan de doden om hen te voorzien van zaken die ze in het leven na de dood nodig hadden. Het paard werd samengesteld uit, in mallen gevormde, onderdelen, vervolgens gebakken en tenslotte 'koud' beschilderd. Het dateert uit de eerste helft van de zesde eeuw (Noordelijke Wei-dynastie). Tot en met de Oostelijke Handynastie (25-220) bestond de tuigage van paarden uit een nog vrij plat zadel, een of meerdere onder-zadeltapijten, het hoofdgestel inclusief de teugels, evenals de borst, buik en kroepriemen. De vroegste stijgbeugels dateren uit het begin van de derde eeuw. Dit vroege voorbeeld laat een aantal belangrijke innovaties zien. Aan weerszijden van het zadel is een spatlap gegespt, die bescherming biedt tegen opspattende modder. Uit de versiering in reliëf kan worden afgeleid dat het in dit geval gaat om de afbeelding van lederen flappen met een ingeperste versiering zoals we die kennen van van $^{\mathrm{B}}$ (come $4: 43: 13 \mathrm{PM}$ 
overigens veel latere Chinese en Tibetaanse lederen koffers uit de Yuan- en Ming-dynastie (1368-1644). Naast leer werden dergelijke flappen ook gemaakt van vilt, boombast of bamboe. Al snel werden de flappen groter, maar dat had als nadeel dat ze de bewegingsvrijheid van paard en ruiter beperkten. Vanaf de Tang-dynastie (618-907) liet men ze weg of werden veel kleinere ronde of ovale flappen gebruikt. ${ }^{7}$

Een ander interessant detail is het dekkleed, de sjabrak, dat voor of na, maar nooit tijdens het rijden over het zadel werd geworpen. Gezien de franjes en de elegante knoop is hier een sjabrak uitgebeeld die gemaakt is van geweven wol. Voorts vallen op de borstriem met een versiering van ongetwijfeld kostbare schelpen en, vermoedelijk van verguld brons gemaakte, hangers aan de kroepriemen, waarmee het zadel aan de achterzijde is bevestigd. Voorwaar een prachtig stuk!

Niet Chinees is de muurschildering (afb. 2) uit het Aphrasiab paleis in het huidige Oezbekistan uit de zesde eeuw, toen de Sogdiërs over dit gebied heersten. De monumentale schildering toont een stoet van ambassadeurs die respectievelijk een olifant, paarden en een kameel berijden. Zij zijn gezeten op zadelkleden van brokaatzijde met een geweven of geborduurd decor. Deze kostbare stukken werden via de verschillende zijderoutes naar China geëxporteerd. Daar werden de decors bestaande uit leeuwen, herten, ever-

Afb. 6

Rolschildering Achttien liederen voor een nomade fluit: Het verhaal van vrouwe Wenji (detail), episode 1: De ontvoering van Wenji, 28,6 x 1196,3 cm., China, vroeg $15^{e}$ eeuw (Ming-dynastie), The Metropolitan Museum of Art, New York. zwijnen, adelaars en heilige ganzen en vooral ook de parelrand, maar al te graag gekopieerd. Niet alleen in textiel, maar vooral ook in keramiek, getuige het welbekende sancai (driekleurig lood geglazuurd) Tang-aardewerk, dat vooral voor grafgiften werd gebruikt. Wonderwel bleef een compleet zadelkleed van geborduurde zijde met deze parelrand-medaillons bewaard (afb. 3).

Dat de Chinezen vooral tijdens de Tang openstonden voor uitheemse invloeden, blijkt uit een tweede keramische graffiguur (afb. 4). Het gaat hier om een vrouwelijke polospeelster. Het is heel opmerkelijk dat deze uit Centraal-Azië geïmporteerde balsport voor ruiters ook beoefend werd door jonge dames van hoge komaf. Die moesten daartoe dan wel een 'Turkse'

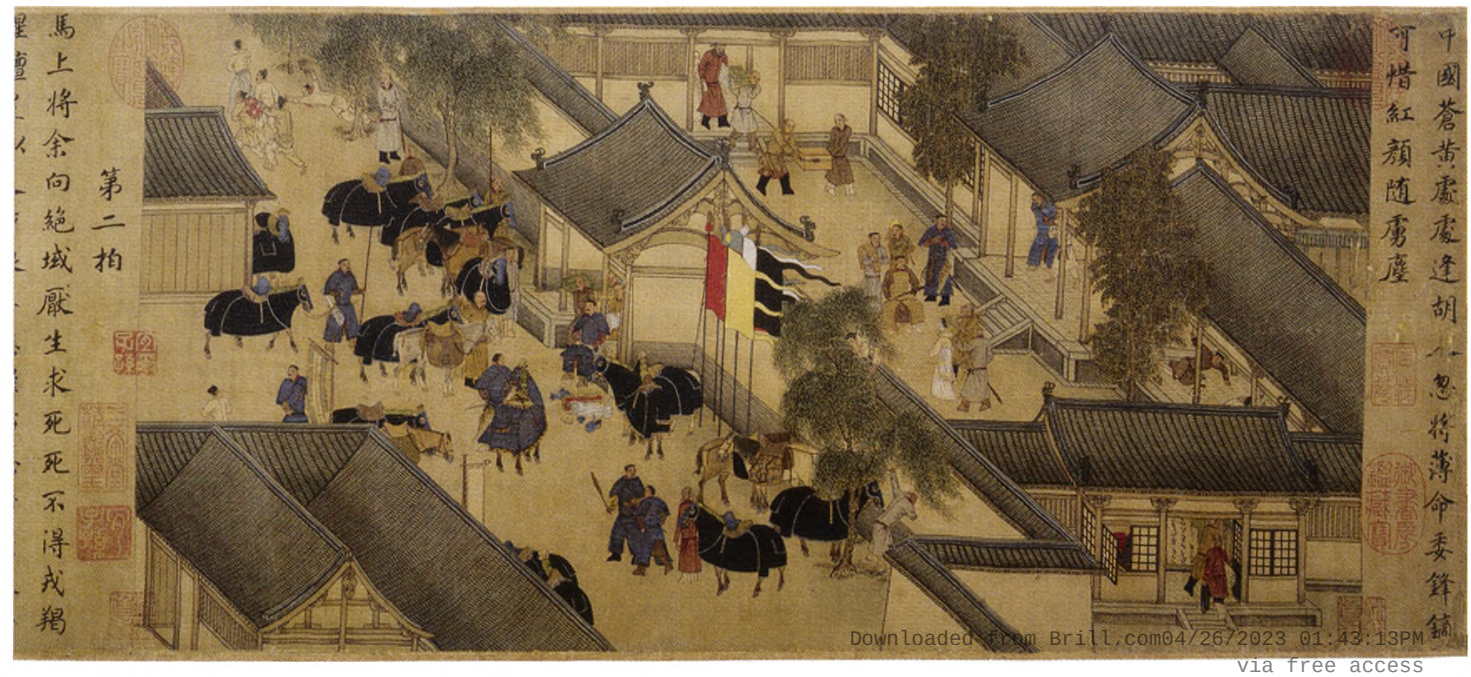


Afb. 7

Rolschildering Noma-

denvorst met concubine

op hertenjacht (detail),

$47 \times 84$ cm., China,

Ming-dynastie,

Galerie Moshe Tabibnia, Milaan.

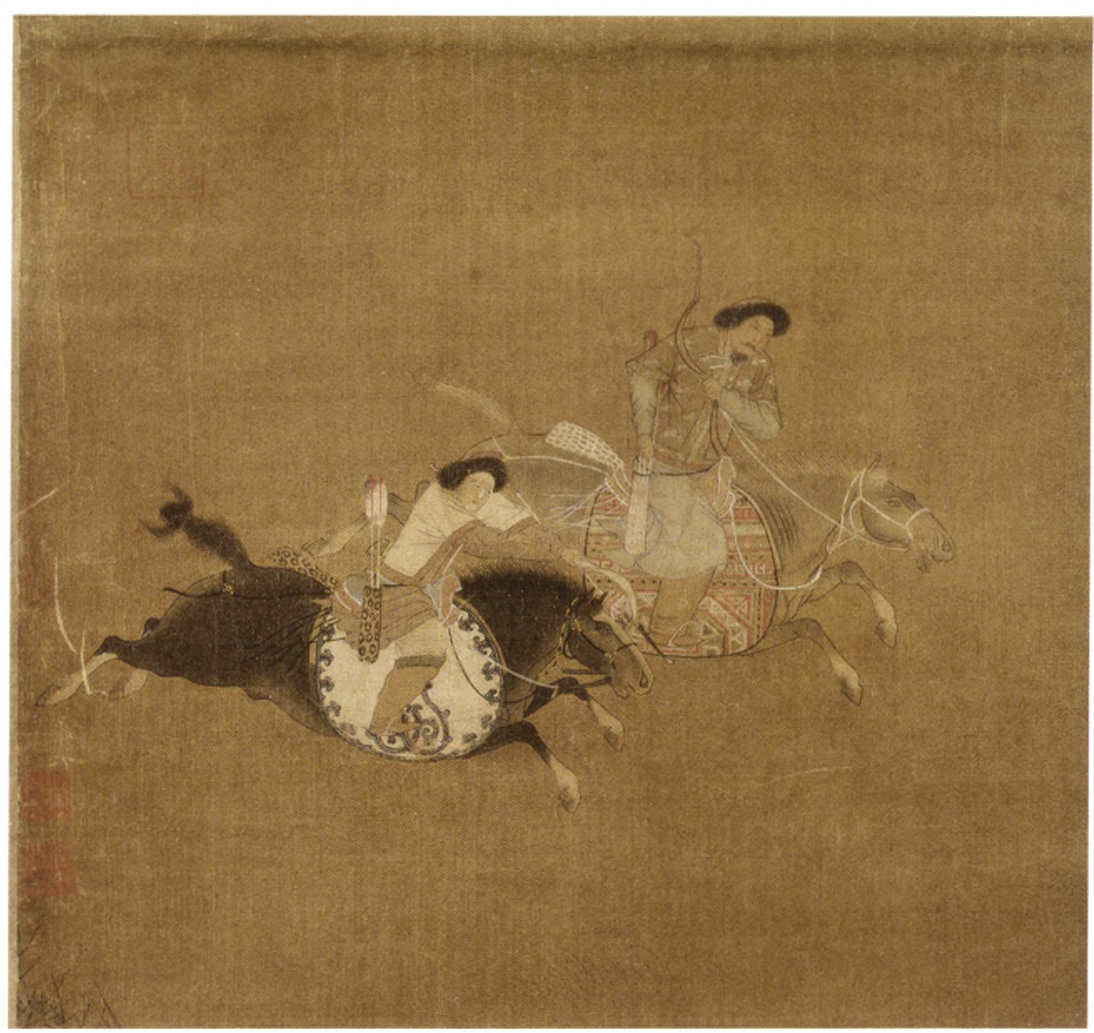

broek aantrekken. Als u goed kijkt ziet $u$ in het midden van het zadeltapijt nog net een deel van een parelrand.

Zadeltapijten gemaakt van tijger- of luipaardvel (afb. 5) en in latere instantie ook de imitaties van geknoopt tapijt ${ }^{8}$ waren van meet af aan, dat wil zeggen sinds meer dan 2000 jaar, een echt statussymbool.

Tegenwoordig zijn ze vooral geliefd bij verzamelaars. Echter, de reden waarom ik deze prachtige rolschildering uit de Song-dynastie (960-1279) uitkoos, is niet vanwege de fraaie voorstelling van een valkenier en een gezadeld rijpaard. Ook niet vanwege de zadelflappen van tijgervel. Ik koos het omdat het zadel is afgedekt met een bovenzadeltapijt dat, naast een comfortabeler zit, diende om de gespen, waarmee de stijgbeugels en de flappen aan het zadel zijn bevestigd, af te dekken. Sindsdien worden sets gemaakt, bestaande uit een lang onder en een korter bovenzadeltapijt, zij het vaker in Tibet dan in China.

Uit de vroege Ming dateert een reeks van in totaal 18 schilderingen die de treurige lotgevallen van Cai Wenji in beeld brengen. Zij werd in 195 door Xiongnu nomaden ontvoerd en gedwongen te trouwen met een nomadenhoofdman bij wie ze verschillende kinderen kreeg. Nadat haar familie de gebruikelijke losprijs had betaald, liet zij haar gezin achter om terug te keren naar haar ouderlijk huis.

De schildering (afb. 6) - het gaat hier naar alle waarschijnlijkheid om een kopie naar een origineel uit de Yuan-periode - toont het moment waarop Cai Wenji uit haar ouderlijk huis wordt ontvoerd. Voor de poort staanna free access 
Afb. 8

Rolschildering Vairavana, Wachter van het Noorden (detail), Dunhuang (China), $9^{e}$ eeuw; Brits Museum (Steincollectie), Londen.

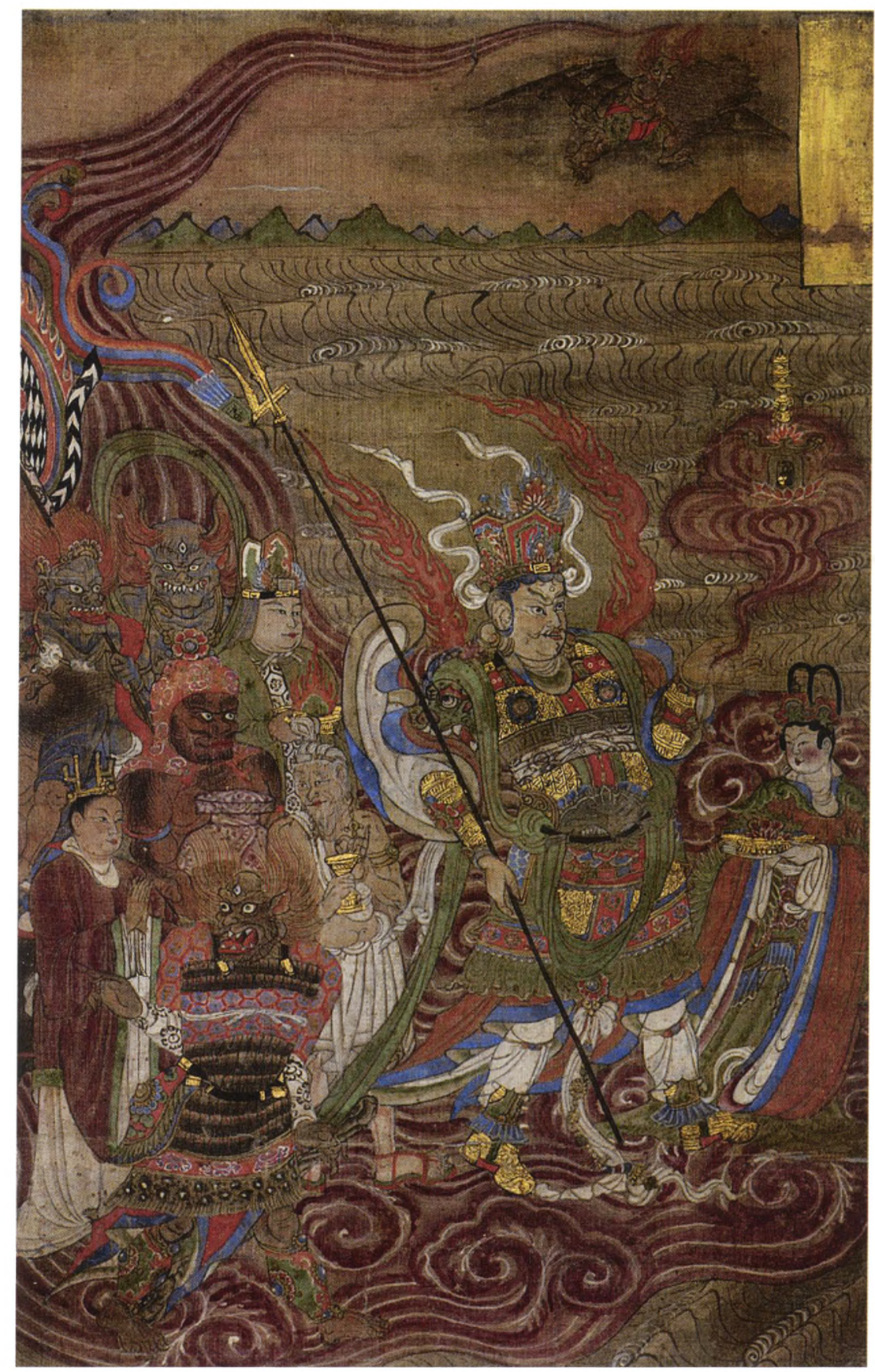

cavaleriepaarden, waarvan het lijf wordt beschermd door middel van een 'jas' van dik vilt, gewatteerde stof of leder. Deze vorm van bepantsering moet dus niet verward worden met de eerder genoemde sjabrak. De paardenhoofden zijn bedekt met maskers. Van een dergelijk masker, in dit geval van beschilderde stof, is voor zo ver mij bekend slecht één exemplaar bewaard gebleven. ${ }^{9}$

Vroeger werd zelden iets weggegooid dat nog ergens voor bruikbaar was. Een dergelijk hergebruik blijkt uit een schildering (afb. 7) uit de Ming-dynastie $e_{3}$ access 
Afb. 9 (links)

Zwart-wit foto

Mongoolse kameel-

ruiter, Nils Hörner,

ca. 1930-35.

Afb. 10

Ningxia kamelenzadeltapijt, pool geknoopte wol op een grondweefsel van katoen, $58 \times 162,5 \mathrm{~cm}$., China, eerste helft $19^{\circ}$ eeuw, The Textile Museum, Washington DC.
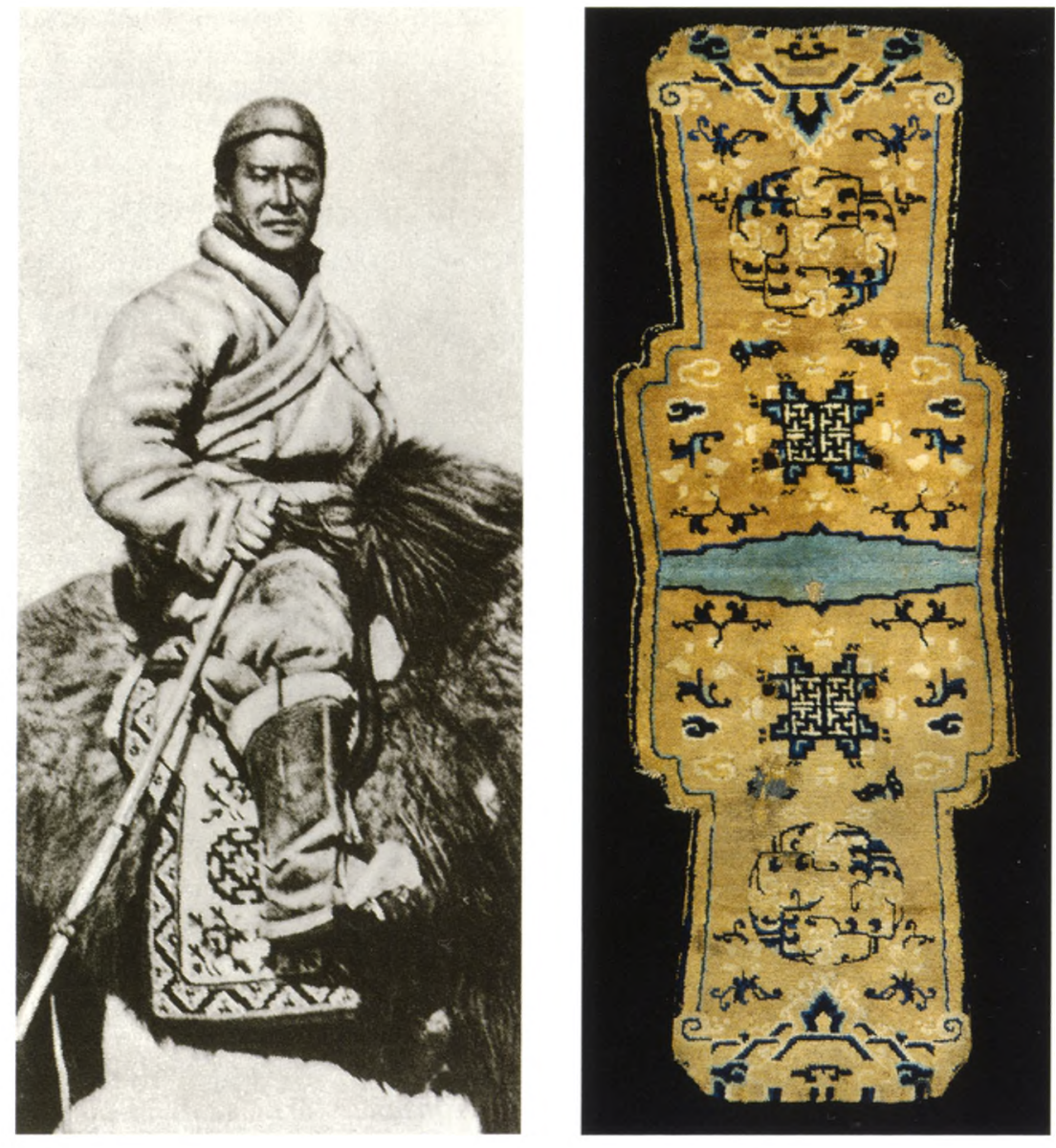

Afgebeeld zijn een Mongoolse vorst en zijn concubine tijdens de hertenjacht. Het paard van de concubine toont een zadeltapijt gemaakt van vilt. Het andere paard is bedekt met een zadeltapijt gemaakt van de resten van een veel groter tapijt, dat alle kenmerken heeft van de tapijten die in Turkmenistan werden geknoopt.

Een rolschildering (afb. 8) uit de Song-periode, gevonden in Dunhuang, stelt Vairavana (Wachter van het Noorden) voor. Deze draagt een flexibel borstkuras, dat is samengesteld uit talloze $y$-vormige schakels van verguld brons of van goud gelakt leer.

Een zeldzaam zadeltapijt van geknoopte zijde uit de Ming-dynastie toont hetzelfde motief. ${ }^{10}$ Tot nog toe werd aangenomen dat het motief ontleend was aan het vlechtwerk van rieten manden. Inmiddels weten we beter.

Een door de Deense fotograaf Niels Hörner in de jaren 30 van de vorige eeuw gemaakte zwart-wit foto vereeuwigde een Mongoolse kameelruiter (afb. 9). Hij zit op een zadeltapijt, waarvan het langgerekte formaat en de symmetrische vorm afwijkt van het gebruikelijke onderzadeltapijt voor paarden. Op basis van deze nieuwe informatie kon een welbekend Ningxia zadeltapijt uit de Qing-dynastie (1644-1911) in de collectie van het Textile Museum in Washington (afb. 10) als een kamelenzadeltapijt worden geidentificeerd from $_{\uparrow}^{01: 43: 13 \mathrm{PM}}$ 

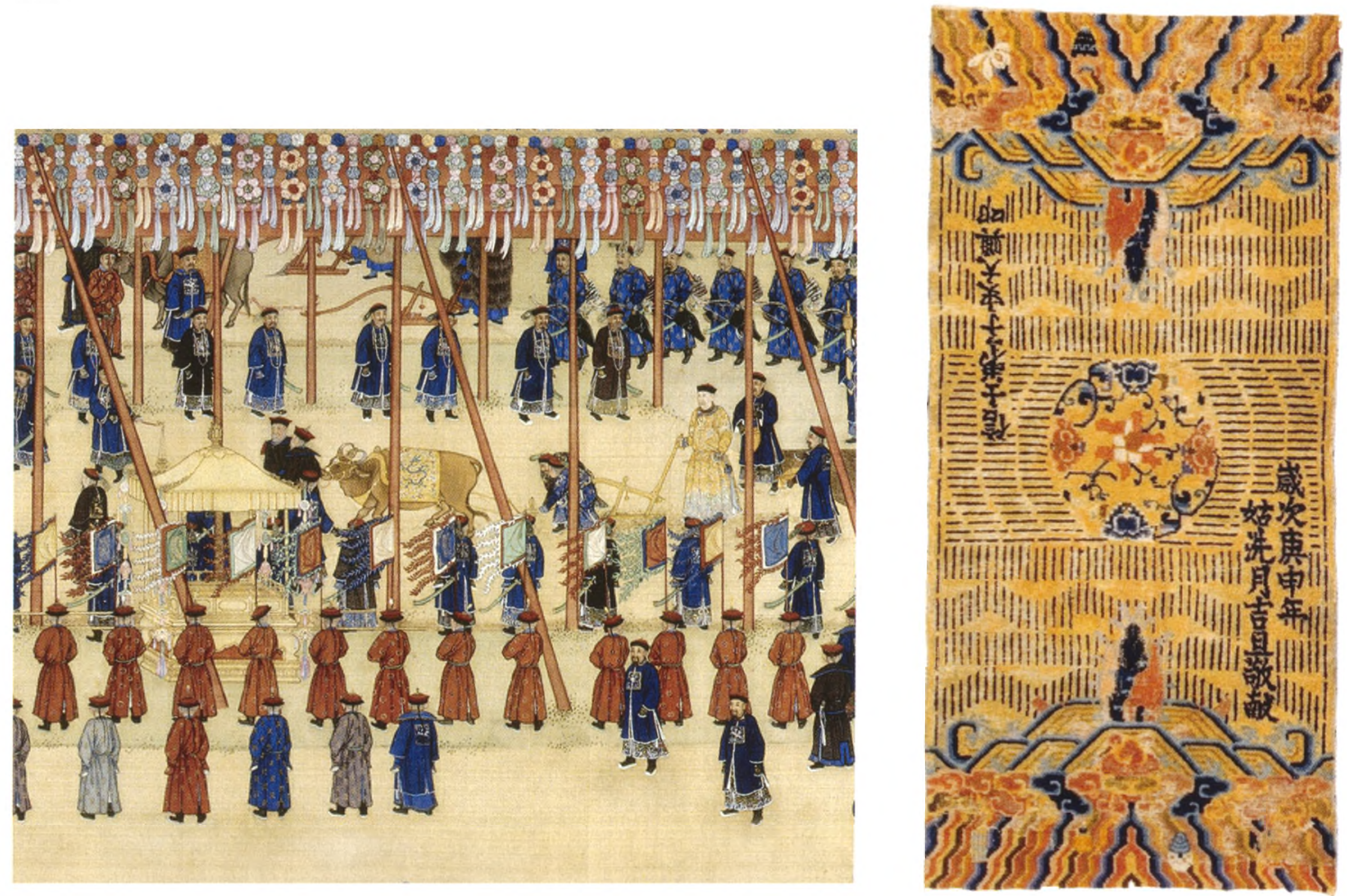

Afb. 1 (links)

Rolschildering (detail) Qingengtu (De Eerste Voor), $63 \times 442 \mathrm{~cm}$., China, 1723-1735 (Yongzheng-periode), Musée Guimet, Parijs.

Afb. 12

Ningxia tapijt met 'RKO' motief en inscriptie, pool geknoopte wol op een grondweefsel van katoen, $70 \times 165 \mathrm{~cm}$. China, gedateerd 1800 , particuliere collectie.
Ook een schildering (afb. 11) uit de tijd van Keizer Yongzheng (1723-35) leverde waardevolle informatie op. Hierin voert de keizer het jaarlijkse 'Ritueel van de Eerste Voor' uit. De voor de ploeg gespannen os is bedekt met een geel Ningxia tapijt, dat versierd is met blauwe draken. ${ }^{11}$ De tekst in een vergelijkbaar Ningxia tapijt (afb. 12) luidt: 'In het jaar gengshen [1800], in de guxi [vijfde maand], eerbiedig aangeboden door de vrome boeddhist Shidaxing'. Sommige auteurs ${ }^{12}$ zien in het tapijt een in tempels gebruikt tafelkleed. Evenwel, het decor met het haishanyün ('zee-berg-wolken') motief aan de beide uiteinden en het merkwaardige, op trigrammen lijkende patroon in het veld van horizontale en verticale banen van streepjes die in geabstraheerde vorm het haishanyün motief herhalen, wijzen veel eerder in de richting van een sjabrak, die tijdens religieuze processies werd gebruikt. Er zijn nog meer argumenten aan te voeren die mijn hypothese ondersteunen, dat dit raadselachtige streepjesdecor ${ }^{13}$ iets van doen heeft met paarden en ceremonies, maar het voert te ver om die hier te behandelen. Laat ik daarom volstaan met het noemen van een rond 1800 gedateerd Ningxia rugleuning tapijtje, dat onlangs door Sotheby's New York werd geveild. ${ }^{14}$ Daarop is afgebeeld een paard met een zadeltapijt, dat eveneens versierd is met op trigrammen lijkende streepjes.

De bovengenoemde rolschildering leert ons dat geknoopte tapijten niet alleen werden gebruikt door 'barbaarse' onderdanen, maar nota bene door de keizer zelf. En ook dat sommige tapijten een ceremoniële functie vervulden, waaruit zowel het decor alsook het afwijkende formaat zijn te verklaren. 
- Koos de Jong is kunsthistoricus (UvA 1976) en was tot 2009 wetenschappelijk medewerker bij het Amsterdams Historisch Museum, directeur van het Provinciaal Overijsels Museum in Zwolle, hoofd collecties bij de Rijksdienst Beeldende Kunst in Den Haag, directeur van de Zaanse Schans/Zaans museum in Zaandam en van het Europees Keramisch Werkcentrum in 's-Hertogenbosch. Sindsdien publiceert hij regelmatig over Chinese tapijten en bereidt hij een dissertatie gewijd aan vroege Chinese miniaturen voor.

\section{Literatuur}

Hans Bidder, Carpets from Eastern Turkestan, Tübingen, 1979. [Oorspr. uitg. 1964]. Wilhelm von Bode, Vorderasiatische Knüpfteppiche aus älterer Zeit, Leipzig, 1901. Michael Franses, 'Forgotten Carpets of the Forbidden City', Hali 173 (2012), pp. 75-87. Michael Franses en Hans König, Glanz der Himmelssöhne. KaiserlicheTeppiche aus China 1400-1750, Museum für Ostasiatische Kunst, Keulen, 2005. [tent.cat.]

Koos de Jong, Dragon \& Horse: Saddle Rugs and Other Horse Tack from China and Beyond, CA-Design, Amsterdam- Hong Kong, 2013.

Koos de Jong, 'Chinese Tapijtkunst', Aziatische Kunst 40/1 (2010), pp. 2-24.

Julius Lessing, Altorientalische Teppichmuster: Nach Bildern und Originalen des XV-XVI Jahrhunderts, Berlin, 1877.

Liu Baojian en Hongqi Yuan, Carpets in the Collection of the Palace Museum, Beijing, 2010. Hans König, 'The RKO Family', Hali 110 (2000), pp. 97-105.

M. Mallett, Woven Structures: A Guide to Oriental Rugs and Textile Analysis, Atlanta, 1998. John Mills, Carpets in Pictures, London, 1977.

Trinley Chodraken Kesang Tashi, Of Wool and Loom: The Tradition of Tibetan Rugs, Orchid press, Bangkok, 2000.

Onno Ydema, Carpets and their Datings in Netherlandish Paintings 1540 - 1700, Walburg Pers, Leiden \& Zutphen, 1991.

\section{Noten}

1. Franses en König 2005.

2. Franses 2012: 75-87; Liu Baojian en Hongqi Yuan 2010.

3. De Jong 2013.

4. Mallett 1998.

5. 'Wetenschappelijk' in Westerse zin. Het behoeft uiteraard geen betoog dat in China de bestudering van teksten, kunstvoorwerpen en oudheden een lange traditie kent, maar deze is vooral literair en volgt een geheel andere methode.

6. Lessing1877; Von Bode 1901; Mills 1977 [en diverse eerdere en latere publicaties]; Ydema 1991.

7. De Jong 2013: 125, afb. 12.07.

8. De Jong 2013: 78, afb. 6.13 .

9. De Jong 2013: 45, afb. 4.06 .

10. De Jong 2013: 60, afb. 5.05 .

11. Een $18^{\mathrm{e}}$-eeuws Ningxia zadeltapijt van hetzelfde formaat en met hetzelfde decor bevindt zich in de collectie van het Palace Museum in Beijing, zie: Liu Baojian en Hongqi Yuan 2010: 262-3.

12. Kunsthandelaar Sandra Whitman, die het tapijt destijds verkocht, deelde mij mondeling mee dat het een tafelkleed betreft. Hans König (2000: 97-105) houdt het voor mogelijk dat dit type tapijt gebruikt werd voor een spel.

13. Door Charles Grant Ellis in zijn artikel 'Chinese Rugs', Textile Museum Journal (1968), Vol. II, no. 3, pp. 35-53, gedoopt tot 'RKO' motief, omdat de streepjes veel weg hebben van de geluidsgolven in het logo van de Amerikaanse RKO filmmaatschappij.

14. Veiling Sotheby's New York, d.d. 11-10-2012, no. 8879. 
Afb. 1

Drie schilderingen in de rechterhoek van zaal 1.5 in het Rijksmuseum.

Anoniem, Drie gezichten op de Parelrivier:

Rede van Kanton,

Rede van Whampoa en

Gezicht op Macao,

olieverf op papier,

gelijmd op doek,

$52 \times 76 \mathrm{~cm}$., China, 1773 Rijksmuseum, inv.nrs.

SK-C-1722, 1723, 1724).

Bruikleen van het Rijksmuseum Volkenkunde.
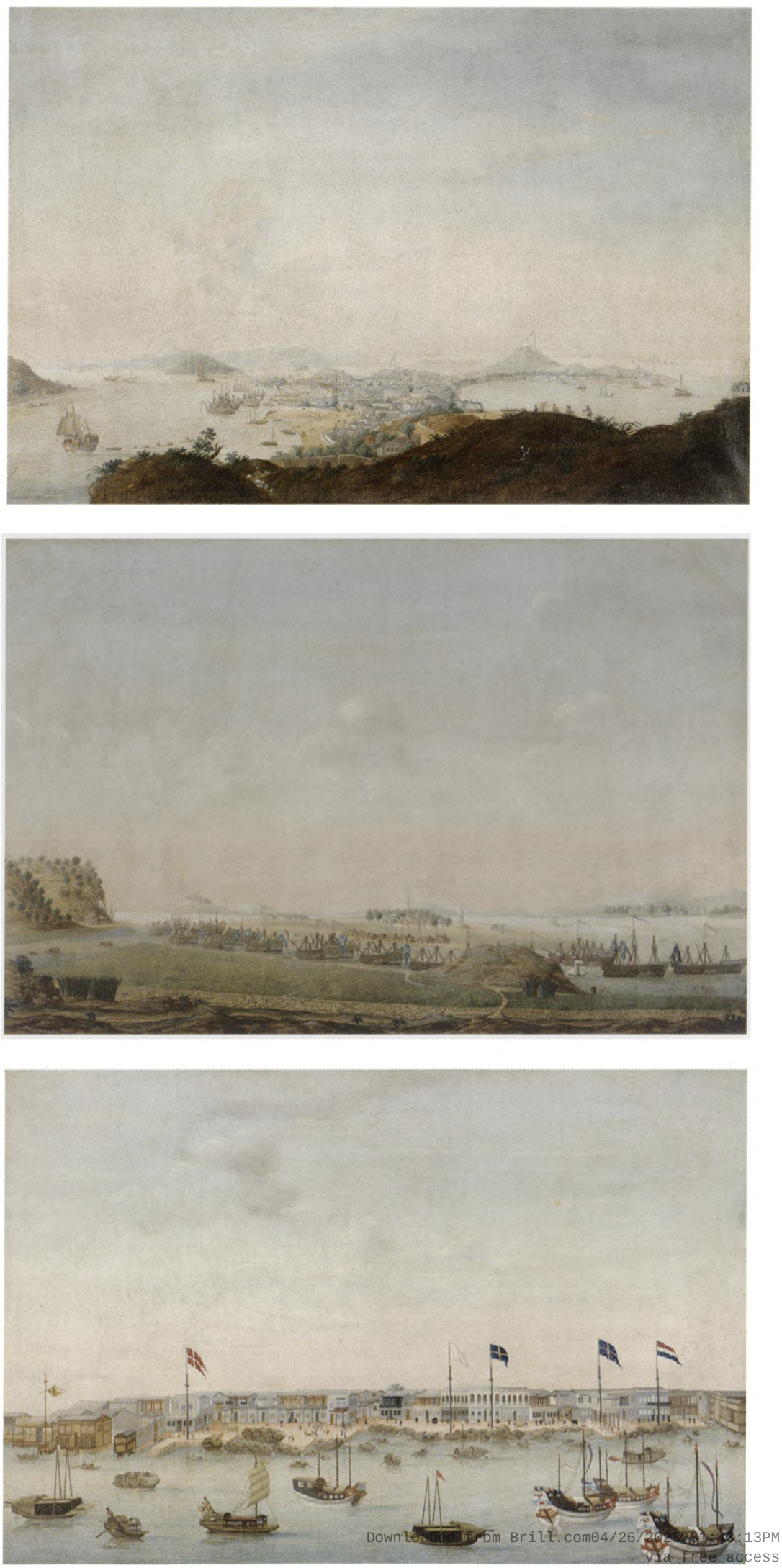